\title{
LEADERSHIP AS A DIMENSION OF TEACHER EFTECTIVENESS
}

\author{
by \\ Dr. S. D. Garba \\ Faculty of Education, \\ University of Sokoto, Nigeria.
}

\begin{abstract}
In the past the teacher has been the focus of attention by critics of teacher performance. Those who view the school from outside hardly think that other factors within the school and outside the teachers control could influence teacher effectiveness.

The classroom is usually regarded as the exclusive domain of the teacher. Students' coverage of contents involvement in classroom activities and students' success at school work are viewed from the standpoint of the teacher. In this paper, the author examines the role of the school leadership in creating the proper working and learning conditions for teachers and students without which teachers efforts would amount to nothing. The author argues that in the new education system being adopted, focus should shift from the classroom teacher to the quality of leadership the school enjoys. Good school leadership can support, enhance and create such essential teacher characteristics as appropriate lesson plans, classroom management, instructional methods that facilitate the achievement of school objectives, high teacher expectation of students, teacher sensitivity to students' emotional and motivational needs and evaluation.
\end{abstract}

\section{Introduction:}

In the past, teacher effectiveness was perceived as the consequence of certain traits or characteristics possessed by the teacher (Peterson \& Walberg, 1979). Teachers, have been held entirely responsible for the effectiveness of their teaching and the success of their students. Those who view the school from outside hardly think that other factors within the school, could influence teacher effectiveness. In recent times however, studies on teaching have added another dimension to teacher effectiveness. The leadership of the principal in a school, is today closely linked to teacher effectiveness and commitment to the school organization (Kunz \& Hoy, 1976). Sweeney, (1982) argues that teacher efforts are frustrated when the school leadership takes the business of school casually. The result is low morale, poor motivation, inadequate planning by teachers, hapharzard instructional methods, chaotic classroom situations and inadequate learning by students. As we begin to implement the new nationai policy on education, there is the need, more than ever before, to focus our attention "on the quality of leadership our school system enjoys. 
The purpose of this paper therefore is to examine some leadership factors and how they enhance teacher effectiveness. What leadership behaviour or style would create conducive atmosphere for the secondary school teacher morale and motivation and what could teachers do to respond to the situation to teach effectively will be discussed. If school leadership creates a conducive atmosphere for teachers to operate well, then what are those positive teacher characteristics that must match the conducive atmosphere to teach effectively? To answer this question, it is necessary to discuss some styles indicative of an effective school leader.

\section{Leadership Dimension}

The importance of strong leadership has been stressed through the literature on instructionally effective schools. Particularly emphasised is the role of the school leadership in having a clear policy with regards to what is expected of teachers' and students' discipline, taking up instructional leadership, having high expectations of pupils' performance and teachers' teaching abilities, good time management, wise resource allocation and staff involvement in school matters and motivation (Moos and Moos, 1979). The principal, is no doubt, a dominant force in the outcome of a school's total instructional programmes. Teachers therefore, rightly expect some kind of behaviour patterns from the principal that indicate to them what they should do as professionals. Some of these behaviour patterns are discussed.

The kind of educational system this country is adopting demands greater qualitative leadership for our schools. As the system is new, its success or failure will depend to a large extent on the type of school leaders we have. Teachers will look up to their school principals, quite rightly so, for direction, support and guidance. What a school leader: could do to create conducive teaching - learning situations are disussed below.

\section{(a) Instructional emphasis}

Evidences abound to show that where instructions lack direction and forms, students' activities do not appear to add up to any productive learning. Using a mixture of management and instructional skills, principals can ensure that it is incumbent on every teacher to be instructionally effective. It will be very difficult for a teacher to avoid classes if he or she knows how serious the principal is about instruction. The cost of instruction at the secondary school as shown in the various states budgets, is so high that no responsible school leader should 
allow a teacher to waste school lessons. If a leader insists on checking lesson plans and teachers' classroom strategies, teachers will take the business of teaching more seriously. Checking lesson plans and observing classroom lessons will help a leader to known how best to help teachers with their work. Frequent classroom visitation, for instance, affords the school leader the opportunity to appreciate better a particular problem with a teacher or a class. The use of continuous assessment should also provide the principal with the necessary information to help keep the school programme on track and to assist teachers in developing and using appropriate teaching strategies.

In the new system, the first three years of secondary education are very critical. Emphasis on appropriate instructional strategies will help reduce wastage in education at this level when the students will have to be retailored to other institutions at the end of the third year or thrown into the nation's job market as graduates of the Junior Secondary School (JSS).

\section{(b) Use of Supervision}

Supervision within the school is an aspect of leadership behaviour. This is not spying on teachers. It is to be used as a means of improving teacher output and solving problem for teachers. Classrooms visits, observations and conferences with teachers, preferably, on individual basis, could be used effectively to help teachers. When teachers come to realise that such supervision are used to help rather than punish them, they will respond positively to the idea. The purpose is to use supervision to stimulate growth among teachers and to facilitate learning by students (Nwaogu, 1980). The division of secondary education in the new system into junior and senior levels, imposes on school leaders the need to use internal supervision constantly and regularly to monitor both teacher and student outputs to carry out quick intervention where and when it is necessary.

\section{(c) Sapport for Teachers}

Teachers are constantly on the look out for the amount of support they have from the principal for the work they do. In the new system being introduced $(6$ $-3-3-4)$, teachers, will more than ever before seek for the suppart and purposeful guidance of their principals. They will feel relieved when they know that they have the support of the principal and develop confidence in their handling of the new system. The support will encourage them to want to try out new ideas, become more and more innovative and creative in order to adequately 
meet the demands of the new system. It will help them generate confidence in their leader and have trust in his actions. Suggestions to the teachers by the leader will be accepted in good spirit especially when they know that such suggestions are not offered to spite them. This way better opportunities will be created towards making the new national education policy a success.

\section{(d) Initiating Programmes}

The capacity of a school principal to initiate, structure and maintain set out standards is very important to the life and success of a school organization. Innovation, after all, is defined as the number of programmes initiated or maintained by a principal to achieve set out objectives and to improve the organizational functioning of the school. A principal's ability to initiate changes in the areas of organizational functioning provides a theoretically important dimension of administrative performance (Miskel, 1979). A principal can modify his school's organizational climate, supervisory leadership and structure of the school for better teacher output by: making personal attitudes clear to teachers, trying out new ideas with teachers, working with a plan that is jointly worked out with the teachers, maintaining a definite standard of performance, emphasizing the meeting of deadlines and using uniform procedures (Garba, 1984). Principals must not assume equality between the old and the new system. In the new system, emphasis is placed on providing opportunities for students to pursue courses they have natural ability for and interest in. What the new system wants to avoid is a situation whereby a person chooses a vocation by accident. Those of us who went through the old system would recall how some of us wanted to take to one vocation but finally ended up doing another. To avoid this kind of situation, it is incument upon our principals in the new system to meet the challenges imposed by the new policy. The importance of initiating new programmes maintaining the existing ones to meet the varied needs of students, cannot, therefore be over-emphasized.

\section{(e) Consideration}

Consideration is a behaviour indicative of friendship, mutual trust, respect and warmth in the relationship between the principal and his teachers (Guest, Hersey \& Blanchard, 1977). As teachers concern themselves with the business of the school, the principal should understand that, they the teachers, have some personal concerns. To help them do their work well, the principal has to 


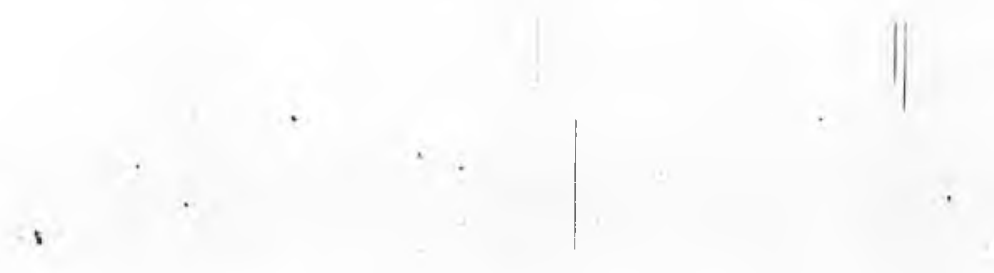

sincerely show them some consideration. No teacher can teach well if he has personal problems. However, the principal can make teachers' work a lot easier, by doing some personal favour for them, making himelf easily understood, listening to them especially when they have complaints or problems, treating them as his equals and making himself approachable. A principal may even volunteer to do extraordinary things for teachers so that they can remain in classes.

\section{(f) Allocation of Resources}

One is yet to see a school that has all the resources it needs. There is always shortage in one area or the other. What is important is not the inadequacy of resources but how the ones available are allocated. Teacher morale and motivation are affected when the school leadership makes them feel that resources at hand are made available only to the so-called favoured individuals. If all teachers understand that schools exist to produce a set of outcomes and that the responsibility for resource allocation is a cooperative one, teachers are apt to manage what they have well and for the general good of the school. Resource allocation must be done in line with the objectives of the school programme.

\section{Creating Conducive School Climate:}

The points discussed so far on leadership are expected to create a climate in the school that will enable teachers to function effectively. Teachers expect, and are expected to work in an atmosphere of peace and orderliness. While it is true that teachers form part of the school environment, yet the conduciveness of that environment is however a factor of leadership within the school atmosphere. When a principal deserts and abdicates his responsibility, efforts of teachers become unco-ordinated and no one knows what is really expected of him or her. A leadership style indicative of abdication hinders innovation and development and a chaotic school atmosphere results which may hamper the success of the new system. However, an effective school climate as created by the leadership behaviour ought to be characterised by discipline, safety, orderlines, innovations and developments for the nation to profit from her investments in the new system. The new system demands a school climate that has a structure, and which system of governance is fair, firm and consistent. Students and teachers know that trouble-makers would be dealt with stringently and swiftly and they know that such punishment whenever it is given out is not arbitrarily or unfairly applied. Principals who promote an atmosphere that is 
orderly without being rigid, quiet without being oppressive and generally conducive to the business of teaching, do with the help of their teachers, develop and communicate plans for dealing with discipline and achievement problems. Feldrebel (1981), argues that much of what is referred to as individual differences in school learning is the effect of particular school conditions rather than basic differences in the capabilities of the students. Whether one accepts this argument or not, one thing is clear though, that students can learn much in the way of attitudes, values, concept of justice and so on from the structure and relationships that they observe and experience in the school. Also, students benefit from attending schools which set standards, where principals and teachers provide good models of behaviour, where they are praised and given responsibility, where the general conditions are good and where lessons are well conducted.

If teachers have to worry about their safety and general well-being, lessons cannot be well conducted. There seems to be too much fragmentation in the new system (for example; two levels at secondary, junior and senior) so that any protracted disruption of lessons at one level is likely to have serious consequences at the next level. Take for example at the junior secondary school level; if certain subjects are disrupted at the JSS level, many students are likely to be denied senior secondary school education due to no fault of theirs. This is why principals must have to fight anything that will disrupt teachers' efforts in planning lessons and conducting them. A conducive school atmosphere should help teachers by providing the necessary conditions for planning and presenting lessons to students. A good climate should enable teachers to demonstrate the kinds of behaviour discussed below.

\section{Teacher Behaviour}

Conducive school climate builds high morale in teachers, high motivation and confidence in what they do. When teachers know that they have the support of their school leaders and come to realize that they themselves are active participants in all that goes on in their schools and they they have no fear for their safety, they are apt to plan their lessons well, manage their classrooms and adopt instructional methods that take into consideration individual differences and needs of the pupils they teach. Their expectations of their students are more than likely to be high because the schools' leader holds such high expectations of the students. Teachers also demonstrate increased sensitivity to their pupils' emotional and motivational needs when planning and presenting lessons to their students. For a teacher to be effective in this type of conducive atmosphere, he must do the following:- 


\section{(a) Planning}

Planning as a teacher behaviour is a process of selecting objectives, diagnosing learner characteristics_and selecting appropriate instructional and management strategies. Diagnosing the learner's characteristics depends on the information about each child made available to the teacher by the school principal. If vital information is withheld from the teacher, wrong diagnosis might be made. Since students have to be distributed to schools according to their interests and abilities, they need adequate information on each child for good planning. When a teacher is able to select appropriately, instructional and management strategies based on students' individual needs, prior learning among the students will be of concern to the teacher. Studies have shown that if deficiencies in prior learning are attended to, most students can learn what was previously learnt by only the best students (Anderson, 1973). For example, deficiencies emąnating from type of primary schools attended by pupils can be reduced. By attending to prior learning in the process of planning a lesson, teachers will be able to reduce, substantially, the effects of students' previous achievement on their final achievement. However a good lesson plan can be helped to succeed only when classroom management is effective.

\section{(b) Classroom Management}

When there is orderliness in the general school atmosphere, teachers are concerned with what goes on in their classes. As the school leadership demonstrates concern for classroom discipline, gives support to teachers, so will teachers be motivated to maintain their classes. The general tendency is for teachers to exhibit all the skills and techniques that are primarily intended to control students' behaviour and are consequently most relevant when attempting to increase students' academic involvement. After all, academic improvement is difficult to achieve if the classroom is not in order. To effectively manage the classroom and improve students' achievement, a teacher must do the following:-

(a) present rules; procedures, expectations, and assignments to students in a clear, detailed manner and establish classroom routines;

(b) establish a system of student accountability for their behaviour and their academic work;

(c) monitor their behaviour and their work and provide feedback on the appropriateness of each;

(d) structure the classroom's physical environment to prevent distractions; and

(e) pace activities so that students become neither confused nor bored and when a classroom is well managed, the teacher's next concern is the emphasis he 
puts on instruction to ensure that concepts are not forgotten and skills are built and developed.

\section{(c) Instructional Method}

Instructional emphasis and evaluation by the school principal induce teachers to become more sensitive of the methods they adopt. Teachers who will respond to the conducive climate created in the school will become increasingly sensitive to their presentation of instruction, practice, performance and the kind of feedback they receive from students. By way of presentation, a teacher reviews the lesson to be taught, provides a review of previously lerrned concepts and skills and goes on to explain what is to be learned and provides reason for why the lesson is important. By and large, instructional method is to depend on the category of students, their emotional and motivational needs. The knowledge of students' background as provided teachers by the school leadership is to provide the basis on which a particular method is preferred to another for a particular class and group of students and how much emphasis needs to be made so that the students learn well. The major concern of a teacher then is choosing an appropriate method of instruction that will enable his student to learn effectively. However instructional emphasis will amount to nothing if the teacher does not expect the students to learn what is being taught. So, instructional emphasis is meaningful if it is coupled with teacher high expectation of the students.

\section{(d) Teacher Expectations}

Teacher expectation of students' ability and performance is an important elements that shapes the teacher's attitudes towards teaching responsibilities and general attitudes towards the students. When teachers' expectation of students are low, the tendency is for teachers to relax efforts in lesson preparation, presentation, classroom management and instructional emphasis. Low expectations of pupils, also lead teachers to fail to help students when they most need their (teachers') support. A teacher will normally act towards a student in accordance with the expectation he holds for that student. Studies have shown that in schools where students consistently perform poorly, teachers in such schools have been more skeptical because they are not expecting their pupils to succeed. However, in such schools where students attain a high degree of success, their teachers have had very high expectations of them (Edmonds, 1979) and above all such teachers readily assume responsibility for teaching their 
students well. Therefore, high teacher expectations of students help teachers to be more particular about how they teach and what they teach. They are likely to spend more time teaching their students and will more than likely not be too general in their approaches to the selection of instructional methods or evaluation. The monitoring of students' progress becomes part of the teaching behaviour with high expectations allowing for flexibility in classroom programming to accommodate variety of students' needs. Having high expectation for students, enables teachers to inculcate in the students a sense that they can succeed and remove the fear of becoming drop outs. Teachers themselves can specifically help students meet high expectations when (1) they are sensitive to the emotional and motivational needs of the students (2) they provide immediate feedback to students, (3) their instructions are directed at the whole class or small groups and (4) they devote more time to the task of teaching. The amount of time a teacher devotes to teaching a particular group is indicative of his commitment to and expectations of the students.

\section{(e) Instructional Time}

Time is a resource. If a lesson is planned for 40 minutes, then it will be difficult to teach the same lesson well in 10 minutes. Classroom content coverage is lost when instructional time is not properly used. If a teacher spends much of class time on irrelevants, or fails to attend the class on time, learning is hampered. Studies have shown that the more time students spend learning a particularly activity, the more they learn (Berliner, Bloom, 1980). If teachers manipulate time well, they can improve' students" learning because the active engagement on the part of both teachers and students in the instructional process is not only a judicious use of instructional time but is attributable to student achievement. To ensure adequate use of instructional time, a principal must spend more time with teachers who handle instructions. Unfortunately, studies have shown that in many schools, especially in Solsoto State, principals spend less than $25 \%$ of their time with teachers or even within their schools (Garba, 1984). Because of that, teachers are often left alone to decide how much time they will spend in a particular class regardless of what is on the schools' time-table. What is nnticed in these schools is complete lack of coordination of teaching efforts and refusal on the part of many teachers to address themselves to important educational issues. If this trend continues then not much success can be expected in the new national education plan. 


\section{(f) Use of Evaluation}

Evaluation serves two purposes: (1) feedback to students, parents and for school record purposes and (2) as a feedback to teachers to find out what they do right or wrong. Evaluation helps teachers to improve the process of teaching and learning. Frequent use of evaluation can also lead to a pleasant, orderly and quiet atmosphere in classrooms and schools which may be conducive to effective learning. When students know that their progress is monitored on continuous basis they are apt to be more serious. Teachers themselves will take the business of teaching seriously if evaluation records are demanded by school leadership before any decision on a child is made.

Whether principals and teachers like it or not, frequent evaluation is entrenched in the new education plan. The plan calls for the monitoring of pupils' progress on a continuous basis to determine the level of success of the individual student, subject and the entire school. To ensure success, frequent evaluation has to be part of a teacher's lesson plan and a school's total school programme.

In any school system the major concern is the product of the system and in this case the student. Good school leadership, conducive school atmosphere and effective teachers are all supposed to have an impact on students. It is expected that in a combined form, products who will meet the needs of the society will be produced, it is also expected that the products will fit into the society and make independent contributions towards the improvement of society. So, having stated all these, what is their impact on the students?

\section{Impact on Students}

Effective school leadership, conducive school climate for teaching and learning and positive teacher response to good leadership and good school climate are expected to have impact on the school's targets - the students. To appreciate the impact, it is pertinent to examine (a) involvement of students during lessons. (b) coverage by students of contents they are taught (c) success (students') in completing assignments or doing well in exams.

\section{(a) Involvement}

Involvement in this regard refers to the amount of time in which students are actively involved in learning specific subject matter. There are two sides to it: How much time a teacher provides for it and how well students are truly and actually engaged during the time provided. Take, for example, a 40-minute 
lesson: the time provided by the teacher is $\mathbf{4 0}$ minutes. If he spends all the 40 minutes judiciously in the classroom, that is the time provided. However, can one say that each student spends all the 40 minutes following what the teacher teaches and similarly.learning along? The more appropriate an instructional method is, the more effective the classroom management is, the greater the student involvement. If a lesson is planned for 40 minutes, then all the time must be used for the purpose with little or no disruption. The number of minutes

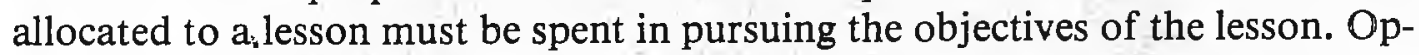
portunities for students' involvement must be provided. The teacher must focus his attention on members of his class and must arouse their interests to ensure their involvement in lessons taught. Adequate involvement of students in class during lessons, leads to greater coverage of contents taught by the teacher.

\section{(b) Coverage}

The second impact on students is their coverage of subject matter taught. For effective coverage, material presented to students has to be appropriate, that is, it has to have some bearing with their prior learning. For example, it is generally assumed that a student has to learn class one mathematics before he can proceed to learn that of class two. Content coverage will be affected if in class one, all the materials for that level were not covered and class two materials have to follow. This is where the planning done by a teacher can enhance or hamper coverage of content by students. However, if care is taken by the teacher to ensure greater involvment, the chances for coverage would have been improved. With coverage of content by students, success is a foregone conclusion.

\section{(c) Success}

Student success is the most important of all instructional variables. When involvement and coverage are at optimal level, success comes as no surprise. Low involvement and low coverage will subsequently lead to low success among students. Success is determined by the extent to which students accurately complete assignments given to them or by how well they perform at tests. For students to succeed in the next higher class, the materials for the present class must be adequately covered by the students. The materials of today's class provide the necessary foundation for the materials of tomorrow's class. Clearly, student's success is dependent upon the student's involvement in class and 
coverage of contents taught. Students' success at school work is not an accidential thing. It cannot be a mistake either. Teachers who aspire to produce highly successful students at whatever level have to take cognisance of the importance of students' involvement in class and coverage of content taught.

\section{Conclusion}

As we begin to think of how to make the new system effective, more attention should be paid to the quality of leadership our school system enjoys. Good leadership generates a conducive school climate for effective teacher performance. A good balance between a leader's ability to initiate and maintain structure and consideration for the staff is essential to ensuring good performance by the teachers and high success by the students.

Efforts of good professional workers are frustrated, more often than not, by poor leadership. The fact is, poor schools do improve when better and more effective leaders take them over. Where good leadership prevails, such teacher characteristics as lesson planning, classroom management, instructural method, high pupil expectation, instructural time and use of evaluation are enhanced. Students on their part will regulate their responses to the demands of the school in accordance with their own perception of the school's leadership commitment to the entire instructional programmes. If the school's leadership demands high quality school work from the students through their teachers, they will respond accordingly. Students' involvement in classroom work, coverage of contents taught and eventual success are measures of leadership of and teacher effectiveness within the school system. Therefore, if the leadership quality of our school system is neglected, we may run the risk of having little or no success when this new system begins. Everything that happens in the school is dictated by the quality of that school's leadership.

Finally, let me call on those who are responsible for forming educational policy for this country to allow this one to germinate, grow and bear fruits before they jump at concluding whether it is useful for us or not. Within two and a half decades we have witnessed many education policies none of which lasted any appreciable length of time to enable researchers determine the effects. These frequent changes have the tendency to confuse school administrators as no trends could be established. Therefore in this country, school management is no small task as policies change within short periods. We have to bear in mind that educational administrators do not operate in a vacuum. They need definite policies to base their management strategies on. If in the course of pursuing certain objectives, additional or new ones are introduced, management crisis is created. We need a consistent educational policy. How long will the 6-3-3-4 system be allowed to last? That is the question. 


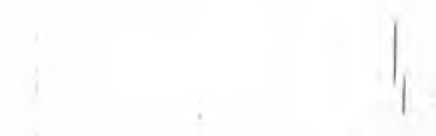

\section{BIBLIOGRAPHY}

1. Anderson, L.W. Instruction and Time-on Task: A Review Journal of Curriculum Studies 1981, 13, $4289-304$.

2. Berliner, D.C.A. Status report on the study of teacher effectiveness. Journal of Research in Science Teaching, $1976,13,4$

3. Bloom, B.S. Human Characteristics and Student Learning New York: McGraw-Hill, 1976.

4. Edmonds, E. Effective schools for the urban poor. Educational Leadership. 1979, $37,1$.

5. Feldrebel, A.M. Leadership for Learning. Seattle: Paper presented at the Annual Meeting of the Conference Professors of Educational Administration. Seattle; August $16-21,1981$. (ERIC Document Reproduction Service No. Ed 212 050)

6. Garßa, S.D. Teacher Behaviour and Student Performance. Paper presented at NTI Zonal Workshop. Makurdi, November 26 - 30, 1984.

7. Guest, R.H., Hersy P. \& Blanchard K.H. Organizational Change through Effective Leadership. Englewood Cliffs: Prentice Hall, 1977.

8. Medley, D.M. Teacher Competence and Teacher Effectiveness. Washington D.C.: American Association of Colleges for Teacher Evaluation, 1977.

9. Miskel, C.G. Principal's Perceived Effectiveness, Innovation Effort and School Situation, Educational Administration Quarterly, 1977, 13, 1.

10. Nwaogu, J.I. A Guide to effective Supervision of Instruction ip Nigerian Schools. Enugu: Fourth Dimension Publishers, 1980.

11. Kunz, D.W., \& Hoy, W.K. Leadership, Style of Principles and the Professional Zone of Acceptance of Teachers. Educational Administration Quarterly; 1976, 12, 1.

12. Perterson, P.L. \& Walberg, H.J. Research on Teaching: Concepts, Findings and Implications. Berkeley: McCutchan Publishing Corporation, 1979.

13. Ryans, D.G. Characteristics of Teachers. Washington D.C.: American Council on Education, 1960.

14. Sweeney, J. Research Synthesis on effective School leadership. Educational Leadership, 1982, 39, 5

15. Walberg, H,J. Educational Environment and Effects Berkeley: McCutchan Publishing Corporation, 1979.

16. Wilşon, K. An effective school principal Educational Leadership, 1982, 39, 5. 